18. Слюсарева Н.А. Проблемы функциональной морфологии современного английского языка. Москва: Наука, 1986. 215с.

19. Структурный синтаксис английского языка. Ленинград: Изд-во Ленинградского ун-та, 1972. 170с.

20. Сусов И.П. Семантическая структура предложения: на материале простого предложения в современном немецком языке. Тула, 1973. 141с.

21. Торсуева И.Г.Детерминированность высказывания параметрами текста Вопросы языкознания. 1986. №1. С.65-74.

22. Уфимцева А.А. Лексическое значение. Принцип семиологического описания лексики. Москва: Наука, 2002. 239с.

23. Чахоян Л.П. Синтаксис диалогической речи современного английского языка. Москва: Высшая школа, 1979. 166с.

УДК $811.111-342$

DOI: $10.24144 / 2617-3921.2020 .18 .143-157$

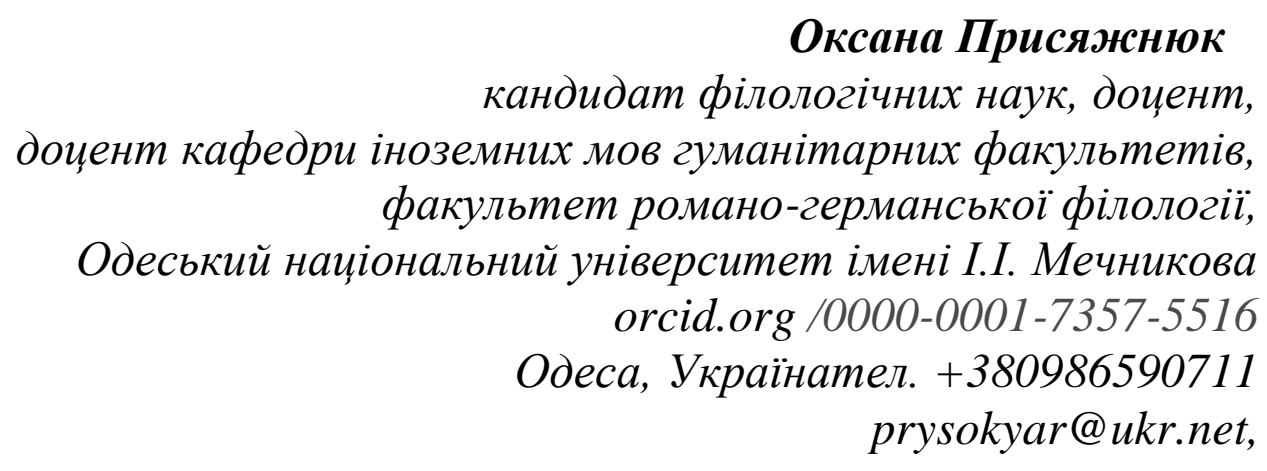

\title{
Сприйняття північних діалектів україномовними білінгвами
}

Анотачія. Стаття присвячена вивченню усної діалектно-забарвленої мови британського типу вимови в аспекті ї̈ сприйняття. Воно спрямоване на вивчення фонетичних характеристик, що відрізняють акценти північного регіону Англії від вимовної норми, а також на виявлення труднощів сприйняття, викликаних лінгвістичною невідповідністю діалектів літературної норми. Актуальність теми дослідження визначається тим, що для досягнення адекватного взаєморозуміння в зв'язку з варіативністю форм мови в різних діалектах національної мови виникає необхідність вирімення ряду проблем взаємодії лінгвістичних чинників літературної норми та регіональних діалектів в процесі мовної комунікації. Метою статті $\epsilon$ виявлення та аналіз характерних рис північних діалектів сучасної Англії, а також визначення глибини сприйняття усного дискурсу носіями орфоепічної 
норми та украӥномовними білінгвами в контексті аудіо записів та письмових транскриптов звучащої мови. У корпус для звукового фонетичного дослідження увійшли 6 монологів - оповідань тривалістю звучання близько 9 хвилин. Суть дослідження полягала в дослідженні глибини сприйняття північного діалекту україномовними білінгвами. В результаті фонетичного аналізу англійської усної мови не тільки була підтверджена гіпотеза, щэо розуміння змісту уривків представляс велику трудність, ніж визначення та характеристика емоцій виражених в тексті, але $i$ виявлено специфічні труднощі процесу сприйняття діалектно-забарвленої мови украйномовними білінгвами. Фонетичні відмінності північних діалектів більшою мірою ускладнюють адекватне сприйняття звучащої діалектно-забарвленої мови україномовними білінгвами, а також носіями англійської мови. Було визначено, що відмінності систем голосних в якісній та кількісній відносинах, а також модифікація приголосних звуків у зв'язному мовлення перешкоджають адекватному розумінню сенсу реципієнтами. Таким чином, в дослідженні, проведеному на матеріалі звучащіх текстів, в результаті другого типу аудитивного аналізу було встановлено, щэо просодія, як складова фонетичного аспекту мови безпосереднім найактивнішим чином впливає на досягнення ефективності комунікаиії. Адекватне декодування інформаџії, закладеної в тембральні характеристики висловлювання, дозволяє оптимізувати процес спілкування між мовиями. Крім того, було визначено, що мовна компетениія реципієнтів не впливає на їх здатність інтерпретувати регіонально маркований текст, а саме сприймати емоиійну сторону усного дискурсу і розуміти зміст тексту.

Ключові слова: регіональні діалекти, фонетика, вимовна норма, білінгви, міжкультурна комунікація, орфоепічна норма.

Abstract. The article is devoted to the study of oral dialect-colored variant of the British type of pronunciation in terms of its perception. The research aims to study the phonetic characteristics that distinguish the accents of the northern region of England from the pronunciation norm, as well as to identify difficulties of perception caused by the linguistic inconsistency of the dialects from the literary norm. The relevance of the research topic is determined by the fact that to achieve adequate mutual understanding due to the variability of language forms in different dialects of the national language there is a need to solve some problems of linguistic factors of literary norms and regional dialects in language communication. The aim of the article is to identify and analyze the characteristics of the northern dialects of modern England, as well as to determine the depth of perception of oral discourse by the speakers of orthoepic norms and Ukrainian bilinguals in the context of audio recordings and written transcripts of the sound language. The phonetic research includes 6 monologues - stories with a sound duration of about 9 minutes. The essence of the study was to study the depth of perception of the northern dialect by Ukrainian-speaking bilinguals. As a result of phonetic analysis of the English oral 
language, the hypothesis confirmed that not only understanding of passages was more difficult than defining and characterizing the emotions expressed in the text, but also revealed specific difficulties in the perception of dialect-colored language by Ukrainian bilinguals. Phonetic differences of northern dialects to a greater extent complicate the adequate perception of the dialect-colored language by Ukrainianspeaking bilinguals, as well as English native speakers. It was determined that the differences of vowel systems in qualitative and quantitative relations, as well as the modification of consonant sounds in coherent speech prevent adequate understanding of meaning by recipients. Thus, in a study conducted on the material of sounding texts, as a result of the second type of auditory analysis, it was found that prosody, as a part of the phonetic aspect of language directly and most actively affects the communication. Adequate decoding of information embedded in the timbre characteristics of the utterance allows to optimize the process of communication between the speakers. In addition, it was determined that the language competence of the recipients does not affect their ability to interpret a regionally labeled text, namely to perceive the emotional side of oral discourse and understand the content of the text.

Keywords: regional dialects, phonetics, pronunciation norm, bilinguals, intercultural communication, orthoepic norm.

Вступ. Стаття присвячена вивченню усної діалектно-забарвленої мови британського типу вимови в аспекті іï сприйняття. Воно спрямоване на вивчення фонетичних характеристик, що відрізняють акценти північного регіону Англії від вимовної норми, а також на виявлення труднощів сприйняття, викликаних лінгвістичною невідповідністю діалектів літературної норми. Актуальність теми дослідження визначається тим, що для досягнення адекватного взаєморозуміння в зв'язку з варіативністю форм мови в різних діалектах національної мови виникає необхідність вирішення ряду проблем взаємодії лінгвістичних чинників літературної норми та регіональних діалектів в процесі мовної комунікації.

Онтогенез відмінності північних діалектів від інших варіантів англійської мови криється в періоді ще до становлення стандартної англійської, а також в періоді найбільш сильного скандинавського впливу, що чинився на ці діалекти, що привів до помітних лінгвістичних відмінностей варіантів даного регіону від діалектів центру та півдня Англії. Таким чином, занурюючись в різноманітність усної діалектно-забарвленої мови, логічно виникає питання релевантне для умов міжкультурної комунікації, якого роду труднощі пов'язані з адекватним розумінням діалектно-забарвленої мови, і яким чином вимова північних діалектів ускладнює сприйняття україномовних білінгвів та впливає на сприйняття мови самими носіями англійської мови.

Питання варіативності діалектної мови за межами вимовної норми всередині британського варіанту англійської мови досить докладно вивчене та описане багатьма лінгвістами. Проблеми синхронічної та діахронічної 
фонології, питання вивчення літературного стандарту, дослідження соціальної та територіальної варіативності мови висвітлювалися такими видатними лінгвістами як В.М. Жирмунській (1956), В.Н. Ярцева (1969), М. Уейклін (1978), М.М. Маковській (1980), Дж. Уеллс (1982), А.Д. Швейцер (1983), O.I. Бродовіч (1988), Дж. Хані (1989), П. Традгілл (1990), У. Лабов (1994), А. Краттенден (2001), Д. Крістал (2001), Р.Я. Кріцберг (2001), А.Д. Травкіна (2001), Т.І. Шевченко (1990) [5;12; 21; 9; 23; 1; 16;20;19;13;14; 7; 10;11] та інші.

Безпосереднім вивченням особливостей північних діалектів займалися і займаються О.І. Бродовіч, С. Дайер, А. Келлет, М. Уейклін, Дж. Уеллс, К. Уотсон, П. Ханібоун, М.М. Маковскій [1; 15; 18; 21; 23; 22; 17; 9] та інші, розглядаючи їх 3 фонетичної, лексичної та граматичної точок зору. Перераховані вище роботи становлять безсумнівний інтерес, оскільки в них накопичений багатий теоретичний матеріал, що стосується теми дослідження.

Однак в цих роботах не вивчалися особливості сприйняття регіональних варіантів британського вимови носіями іншої мови, специфіка розуміння та інтерпретації регіонально - маркованої усної мови, а також вплив фонетичних процесів в зв'язного мовлення на рівні розуміння.

Як виходить 3 досліджень британських соціолінгвістів та фонетиста П.Традгілла [20], акцент розглядається як тип вимови, а діалект як варіант мови, що має відмінності від мовної норми на вимовному, граматичному та лексичному рівнях. При встановленні ареалу розповсюдження сучасних північних діалектів в Великобританії за основу нами була прийнята класифікація діалектів, запропонована А.Еллісом та П.Традгіллом, які до північних діалектів відносили регіони Нортамберленд, Камберленд, Дарем, Уестморленд, Йоркшир, Ланкашир. Обраний синхронічний підхід дає можливість виявити, проаналізувати та детально охарактеризувати особливості північних діалектів на всіх трьох рівнях: фонетичному, граматичному та лексичному.

Метою статті є виявлення та аналіз характерних рис північних діалектів сучасної Англії, а також визначення глибини сприйняття усного дискурсу носіями орфоепічної норми та україномовними білінгвами в контексті аудіо записів та письмових транскриптів звучащої мови.

У корпус для звукового фонетичного дослідження увійшли 6 монологів - оповідань тривалістю звучання близько 9 хвилин, а також список фраз без урахування графічних кордонів слів, записаний у вигляді фонетичного слова на північному діалекті для дослідження сприйняття письмового тексту. Обов'язковою умовою при відборі усних та письмових текстів для проведення фонетичного дослідження була наявність в них характерних рис північних діалектів, що містять фонетичні, лексичні та граматичні труднощі сприйняття англійської мови на слух.

Експериментальний матеріал за двома типами досліджень склали письмові транскрипти усної мови та автентичні записи у виконанні носіїв 
північних діалектів. Матеріалом для аналізу по першому типу дослідження послужили фрази на північному діалекті, записані у вигляді фонетичного слова. Як відомо, в слові реалізується план вираження - фонемно-фонетична структура та план змісту - лексичне та граматичне значення. Слово може зазнавати певних змін, «притягаючи» до себе ненаголошені службові слова і частки та утворюючи фонетичне слово. Слід також вказати на складність самих експериментів у цій галузі. Графічна фіксація усного мовлення, з одного боку, будучи штучним способом іiі репрезентації, оскільки відбувається підміна слухового сприйняття зоровим, спотворює сприйняття, а 3 іншого боку, є необхідним етапом лінгвістичного аналізу [3: 20].

Всі запропоновані для аудитивного аналізу варіанти фраз були відібрані за принципом підпорядкування правилам модифікації голосних та приголосних у спонтанному мовленні, характерною для носіїв сучасних північних варіантів англійської мови. Завданням реципієнтів було дати розшифровку фразам та запропонувати транслітерацію записів відповідно до нормативних правил вимови. Перевірялася ступінь розуміння мовцями особливостей північних діалектів. В якості експериментального корпусу по другому типу перцептівно-фонетичного дослідження були використані звучащі тексти, що відносяться до художніх творів, серед яких були: художнє читання, діалог, сценічний виступ актора. Звуковим матеріалом для аналізу слугували: аудіо книга автора, оповідача, оратора та викладача з Йоркшира Дж.Фіні «The Little Village School», а також сценічний виступ актора-коміка Пітера Кея «Live at the Top of the Tower», що представляє спонтанну мову 3 провокацією слухачів на більш емоційне сприйняття. Провідними критеріями при відборі експериментального матеріалу слугували: вид усного дискурсу, форма його реалізації та, як наслідок, стиль мови. За твердженням М.В. Давидова, основною метою художнього тексту є естетичний, емоційний вплив на слухача, відповідно просодія даного регістра буде більш варіативною ніж просодія наукового регістра [4: 77].

Що стосується спонтанного мовлення, то усне монологічне мовлення важке для сприйняття, оскільки володіє великим ступенем спонтанності, а також супроводжується не тільки лінгвістичними, а й паралінгвістичними явищами [8: 10]. Слід зазначити, що для дослідження були відібрані такі епізоди, які відображають характерні риси північних діалектів, що містять лінгвістичні та паралінгвістичні труднощі сприйняття англійської мови на слух. Звісно ж, що ці випадки в найбільшою мірою відповідають меті цього дослідження.

Досліджуваний матеріал представлений 6 уривками різної тривалості у виконанні різних дикторів - чоловіків, загальний час звучання склало близько 9 хвилин. 3 метою визначення різниці в ступені сприйняття модифікованої діалектно-забарвленої мови та отриманні об'єктивних даних про глибину розуміння та інтерпретації специфіки північних акцентів, як носіями англійської мови, так і україномовними білінгвами було проведено фонетичне 
дослідження, в якому взяли участь студенти 3 та 5 курсів денного та заочного відділень факультету англійської філології МГУ, а також запрошені носії англійської мови (переважно студенти вузів Великобританії). Дослідження проходило на кафедрі іноземних мов гуманітарних факультетів РГФ ОНУ 3 2018 по 2020 рік.

Гіпотезою дослідження послужило положення про те, що труднощі сприйняття усної діалектно - забарвленої мови носіями англійської мови та україномовними білінгвами полягає не стільки в невідповідністі лексикограматичних форм, скільки в фонетичних відмінностях північних діалектів від стандартного варіанту англійської мови.

Крім того, викликає сумнів твердження, засноване на аудиторському аналізі із залученням носіїв англійської мови, що «мова 3 елементами Йоркширського діалекту не викликає особливих труднощів при її сприйнятті жителями Великобританії», а «найбільші труднощі при сприйнятті мови носіїв діалекту україномовними білінгвами пов'язані 3 нерівним темпом проголошення, 3 невірною акцентуацією смислових частин тексту, «горловим характером голосу» [8]. Нам видається, що труднощі сприйняття та розуміння мови носіїв північних діалектів, зафіксовані письмово, будуть виникати в рівній мірі як у україномовних білінгвів, так і у носіїв англійської мови, і будуть ускладнюватися не тільки просодичними особливостями, а й в більшій мірі фонетичними характеристиками північних акцентів.

В ході перцептивно-фонетичного дослідження необхідно було вирішити кілька завдань, а саме: 1) дослідити характер сприйняття регіональних особливостей мови сучасними британцями; 2) вивчити характер труднощів, що виникають при сприйнятті діалектно-забарвленої мови україномовними білінгвами; 3) порівняти сприйняття регіонально маркованої англійської мови україномовними білінгвами та британцями.

Методологія та методи дослідження. В якості основних методів дослідження були обрані метод аудитивного аналізу, анкетування, кількісна обробка даних, що дозволяє оцінити середній вимір i, таким чином, судити про надійність отриманих даних. Метод анкетування реципієнтів включав аналіз транскриптов усної мови у вигляді записаних пропозицій в двох групах - групі А, що включала мовців, для яких англійська мова була рідною та групі Б, куди входили носії української мови. Анкетування реципієнтів проходило за методом сприйняття «знизу - вгору» (тобто від окремих частин, ознак і т.п. до опізнання цілого через їх підсумовування) і подальше заповнення анкет. Був застосований аналітичний спосіб аналізу матеріалу, тобто 3 опорою на графічну транскрипцію.

Група А. Реципієнтами першої групи виступили «наївні» носії англійської мови: чоловіки та жінки у віці від 20 до 25 років, в даний час проживають в Лондоні (19 осіб). Група Б. Друга група реципієнтів складалася з україномовних білінгвів у віці від 18 до 23 років - учні 3 та 5 курсів 
факультету англійської філології МГУ, які вивчають орфоепічну норму британського варіанту англійської мови (19 осіб).

Для перевірки твердження про те, що слухове відчуття є домінуючим при сприйнятті мови, але не призводить до розуміння змісту, а просодія служить одним 3 індикаторів психоемоційного стану мовця в момент мовлення, був проведений другий тип дослідження - аудитивний аналіз текстів монологічного мовлення, коли реципієнт виносить судження про матеріал, заснований на його сприйнятті. Метою дослідження було визначення ступеня розуміння діалекту та виявлення основних труднощів, що виникають при сприйнятті північних варіантів англійскої мови людьми, які вивчають англійську мову, вимова яких відповідає літературній нормі англійської мови.

Для опису моделі сприйняття був проведений аудитивний аналіз, в ході якого вирішувалося два комплексу завдань. Перший комплекс складався в аналізі глибини розуміння змісту. Другий комплекс полягав в психолінгвістичному аналізі емоційності висловлювань. Завдання дослідження були визначені в такий спосіб: 1) дослідити сприйняття реципієнтами регіональних особливостей на слух під час прослуховування аудіозаписів епізодів художнього твору з точки зору розуміння та оцінки змісту уривків; 2) провести психолінгвістичний аналіз прослуханого на сверхсегментному рівні. Дослідження було також направлено на винесення емоційної оцінки діалектної мови реципієнтами. При цьому обов'язково прослуховувався кожен текст цілком, щоб уникнути реакції на манеру говоріння.

Об’єктивність дослідження досягається завдяки отриманим результатам.

На цьому етапі дослідження реципіснтами виступали учні 3-х курсів денного та заочного відділень, а також студенти 5-го курсу денного відділення факультету англійської філології МГУ. Загальна кількість реципієнтів склала 147 чоловік. Методи аудитивного аналізу та анкетування включали прослуховування епізодів в малих групах та подальше заповнення анкет. Був застосований синтетичний спосіб прослуховування матеріалу, коли аудитори працювали без опори на графічну транскрипцію, тобто в умовах максимально наближених до природного спостережування при сприйнятті усного мовлення. Питання, пропоновані реципієнтам в анкеті, були спрямовані на визначення ступеня сприйняття діалектно - забарвленої мови та виявлення основних труднощів, що викликають низький рівень глибини розуміння.

У даній роботі проводилося вивчення відмінностей в мові носіїв північних діалектів на вимовному рівні. У роботі в першу чергу досліджувалася ступінь сприйняття реципієнтами фонетичних особливостей регіональних варіантів на вимовному рівні, що перешкоджають адекватному розумінню змісту епізодів.

Однак оскільки в мові мовців 3 певним територіальним акцентом неминуча поява специфічних діалектних особливостей, під час проведення 
фонетичного дослідження реципієнти були попереджені, що мова в запропонованих для сприйняття епізодах не витримана в стандарті англійської мови, а була діалектно - забарвлена. Реципієнти повинні були послідовно прослухати 6 аудіо-уривків усної мови різної стильової спрямованості, починаючи з більш легкого та закінчуючи найбільш важким для розуміння епізодом.

Після закінчення прослуховування кожного з уривків вони заповнили спеціально складені анкети, які містили від 4 до 7 питань. При прослуховуванні озвучених текстів реципієнти виконували наступні завдання: перші три питання ставилися безпосередньо до психометричного аналізу, тому що ним пропонувалося охарактеризувати емоції, виражені мовцями на уривку, вказати подобається або не подобається даний текстовий фрагмент, чим саме подобається (дикція, милозвучність, голос, мелодія), а також манеру оформлення мови мовця.

Наступний тип завдань в анкеті був направлений на перевірку ступеня розуміння змісту прослуханого уривка. Завдання полегшувалося тим, що реципієнти мали перед собою питання множинного вибору, які були сформульовані таким чином, щоб з'ясувати деталі того, що відбувається в епізодах.

Крім питань в анкеті пропонувалося завдання, пов'язане зі сприйняттям або здогадкою значення діалектальної лексики, коли реципієнти повинні були «перевести» взяті 3 контексту речення, що містять регіонально марковані форми мови на стандартну англійську (наприклад, Nay, lad, thee carry on.)

Крім студентів, в якості реципієнтів були також запрошені фахівці в області фонетики англійської мови, що мають великий досвід аудіювання. До пред'явлення матеріалу студентам, експериментальний матеріал був проаналізований 3 точки зору можливих труднощів для сприйняття на граматичному, фонетичному та лексичному рівнях. В ході аналізу письмових транскриптов, проведеного фонетистами-експертами, була складена фонетична транскрипція записаного матеріалу, яка відповідала б виголошення експериментального матеріалу в повному стилі вимови. На основі фонетичної транскрипції були визначені характерні особливості північних діалектів на лексичному, граматичному та фонетичному рівнях, куди входили як асимільовані форми, так і відмінні фонетичні риси. Для більшої об'єктивності дослідження нами був також проведений аналіз просодії звучащіх текстів на матеріалі другого типу фонетичного дослідження. Цінність даного аналізу полягає в тому, що він дозволив 3 достатнім ступенем об'єктивності визначити модальність пропозицій в епізодах, а також наочно уявити варіативність фонетичних, просодичних та паралінгвістичних компонентів.

Для аналізу результатів, отриманих в ході проведення фонетичного дослідження, був розроблений параметр адекватності інтерпретації діалектнозабарвленої мови. Розглядалися чотири ступені точності інтерпретації змісту фрази: 0 - відсутність відповіді та відсутність інтерпретації (реципієнт 
утримався від відповіді); 1 - невірна відповідь - низька ступінь адекватності інтерпретації (реципієнт запропонував неправильний варіант); 2 - неточна відповідь - задовільний ступінь адекватності інтерпретації (реципієнт запропонував правильну відповідь 3 однією помилкою на одному 3 рівнів. Наприклад, було дано невірний еквівалент займенника (I замість уои) або допоміжного дієслова (has замість have); 3 - пошук правильної відповіді (реципієнт правильно зрозумів пропозицію, записав його, щоб виконувати всі фонетичні, граматичні і в деяких випадках лексичні відмінності). Це - високий ступінь адекватності інтерпретації.

При аналізі результатів відповідей реципієнтів була застосована кількісна обробка експериментальних даних.

Виклад основного матеріалу дослідження. Розглянемо дослідження в групі A, отримані в ході роботи з першою групою реціпієнтів, а саме носіями англійської мови (19 осіб). У групі А при аналізі транскриптов усної мови спостерігалася висока ступінь адекватності інтерпретації змісту діалектно забарвленої мови (60\% вірних відповідей). Носії мови точно визначили значення фраз, незважаючи на наявність в них фонетичних особливостей північних акцентів, наприклад:

а) якісні та кількісні зміни голосних, монофтонгізація дифтонгів.

Nardendee, wotdardooin? - Now then dear, what are you doing?

Eessezitintiz burraberritiz. - He says it isn't his but I bet it is.

Abberritinterz. -1 bet it isn't hers.

б) асимілятивна зміна приголосних:

Lerrus gerrus andswesht. - Let us get our hands washed.

Corforus arpastate itmornin. - Call for us at 8.30 in the morning.

Носії мови не відчували труднощів, інтерпретуючи такі фонетичні явища, характерні для північних варіантів англійської мови, як: елізія /s/, /v/, /h/, /th/ на кінці слова, перехід /th/-/d/ (випадок часткової регресивної асиміляції); реалізація /t/ - /Г/; / in//m /; випадання голосного в певному артиклі - itmornin; компресія слів, наприклад something - Summatsupeer; кількісна редукція; втрата початкових голосних або складів у слові - of course, about; Supwidee? - What's up with you?

Задовільний ступінь адекватності інтерпретації змісту запропонованого матеріалу реципієнтами групи А спостерігався в більшості випадків визначення граматичних невідповідностей. Так, безпомилково сприймалися діалектно-забарвлені варіанти 'As tha' = 'Have you'; 'Is thee' = 'Are you'; випадки подвійного заперечення в реченні: 'Ayampt eared nowt' = 'I have not heard nothing' = 'I have not heard anything'. Однак простежувалися труднощі в правильному визначенні займенників. Не всіма реципієнтами - носіями мови, були вірно вказані варіанти займенників 'tha' та 'us', а також узгодження підмета 3 допоміжним дієсловом. Звідси 12\% відповідей, які з'явилися не цілком коректними, але не перешкоджають розумінню основного змісту речення. Цікаво відзначити, що деякі реципієнти групи А запропонували не 
тільки в іiі первісному вигляді розшифровку діалектної фрази, а й далі іiі еквівалент, який використовується в стандартній англійській та є коректним лексично, граматично та стилістично. Наприклад, фраза, прийнятна для розмовного стилю 'Something's up here' була інтерпретована як 'Something is going on' або 'Get it eaten'. - 'Eat it all up'.

При аналізі результатів дослідження враховувався той факт, що в групі А особистий мовної та соціокультурний досвід реципієнтів міг вплинути на їхні відповіді. Наявність невеликої кількості сленгових виразів не поставив у складне становище жодного з реципієнтів.

Eez gunna gerra lorra lolly forrit. - He is going to get a lot of money for it.

Weerz gaffer? - Where is the boss?

Issthemum? - Are you keeping quiet?

Дослідження показало, що, в цілому британці, які взяли участь в дослідженні здатні ідентифікувати регіональні типи вимови, а також розрізняти нормативну та регіональну вимову, в нашому випадку північні акценти. Однак форма пред'явлення матеріалу у вигляді письмових транскриптов ускладнила сприйняття, внаслідок чого у носіїв пропав інтерес до виконання завдання. Труднощами вірного розуміння фраз з'явилася складна система транслітерації та запис речення у вигляді фонетичного слова, одним ланцюжком.

Механізм внутрішнього промовляння, властивий сприйняттю в рецептивних видах мовленнєвої діяльності, якими є аудіювання та читання залишився слабо активізованим або не привів реципієнта до позитивного прогнозування шуканого варіанту еквівалента діалектно - забарвленої фрази у вимовій нормі. Так, було отримано лише 4\% негативних відповідей, що свідчить про низький ступінь адекватності інтерпретації, а $24 \%$ питань було залишено без відповіді як перша реакція на побачене в анкетах (повна відсутність інтерпретації). Це може бути пов'язано з психологічною реакцією відторгнення та втратою «інтересу» до інтерпретації речень в зв'язку зі складністю транслітерації. I в цьому плані в якійсь мірі має право бути застосованим і до варіантів однісї мови висловлювання С. І. Бернштейну про те, що негативний ефект іншомовного акценту на слухача відображає неусвідомлену форму «протесту проти примусу до непродуктивної розумової енергії» [2: 36].

Розглянемо результати, отримані при аналізі анкет реципієнтів групи Б, в яку входили україномовні білінгви (19 осіб). У даній групі реципієнтів відсоток вірних відповідей склав лише $11,7 \%$, тобто високий ступінь адекватності інтерпретації діалектно - забарвленої мови спостерігалася у значно меншого числа реципієнтів групи Б в порівнянні з групою А, де 60\% слухачів дали вірну відповідь.

Аналізуючи протоколи 3 відповідями, ми відзначили, що реципієнти групи Б в більшості випадків правильно інтерпретували фонетичну модифікацію приголосних та деяких голосних. Однак, наприклад, опущення 
фарингального / $h$ / ввело в оману багатьох реципієнтів, що перешкоджало правильному сприйняттю фрази. До подібних прикладів можна віднести наступні речення, залишені без розшифровки. Ees gorris atooam. - He's got his hat on him.

Lerrim purrizaton. - Let him put his hat on.

$\mathrm{y}$ деяких випадках реципієнтами групи Б була вгадана частина пропозиції, що включає в себе найбільш поширені фонетичні характеристики північних акцентів. Але, хоча окремі слова пропозиції були визначені правильно реципієнтами, загальний зміст залишався незрозумілий. $23 \%$ невірних відповідей - свідчать про низький ступінь адекватності інтерпретації аналізованої фрази. Найбільші труднощі при визначенні значення пропозицій можуть пояснюватися тим, шо випробувані не провели членування фонетичного слова, розглядаючи його як одну лексичну одиницю.

Як свідчать дані аудитивного аналізу, транслітерація для цієї групи служила підказкою, а не відволікаючим моментом в інтерпретації діалектних фраз, як у випадку 3 першою групою носіїв мови. Більший відсоток пропозицій, залишених без відповіді $(57,5 \%)$ можна пояснити незнанням реципієнтами групи Б основних фонетичних та асимілятивних характеристик північних акцентів, відсутністю соціально-культурного досвіду сприйняття, а також недостатньою сформованістю навички сприйняття діалектнозабарвленої мови (реципієнти групи Б були знайомі 3 теоретичного курсу фонетики лише 3 основними характеристиками північних акцентів). Задовільний ступень адекватності інтерпретації змісту запропонованого матеріалу реципієнтами групи Б спостерігався на граматичному рівні.

Thakkan iftha wanto. - You can if you want to.

Asia gorrit withy? - Have you got it with you?

У даних прикладах учасниками дослідження був вірно визначений займенник 'tha' та його форми. Однак труднощі для інтерпретації в ряді випадків проглядалася відповідно допоміжного дієслова і займенники. 'Has tha' - 'Has you'. У деяких випадках займенник 'tha' приймався за певний артикль 'the' або за особистий займенник he / they. Так само як і в групі А, такі похибки в перекладі, що не перешкоджають розумінню загального змісту, були віднесені до другої ступені точності інтерпретації фрази, що вилилося в $7,8 \%$ зарахованих відповідей.

На лексичному рівні наявність труднощів для сприйняття (незнання сленгу) завадило правильної інтерпретації речень та стало результатом великої кількості помилок у відповідях групи реципієнтів Б.

За результатами фонетичного дослідження після аналізу та порівняння протоколів 3 відповідями англійців та україномовних білінгвів встановлений різкий контраст в глибині сприйняття та ступені точності інтерпретації фраз, поданих в транскриптах, що відображають сучасну мову носіїв північних акцентів. Було визначено, що ідентифікація регіональних акцентів становить 
велику складність для російськомовних реципієнтів, ніж для британських (4\% невірних відповідей в групі А, проти $23 \%$ в групі Б).

Важким для україномовних білінгвів виявилося те, що фрази включали в себе не тільки особливості вимови, зафіксовані орфографічно, але і лексичні та граматичні відмінності. Таким чином, реципієнти обох груп зіткнулися 3 труднощами на двох рівнях інтерпретації. Перший рівень полягав в необхідності визначити відмінності діалектних фраз від стандарту на всіх рівнях як фонетичному, так і граматичному. Другий рівень інтерпретації фраз був перекладом речень на стандартну англійську з урахуванням лексичних та стильових особливостей.

Проведене дослідження по інтерпретації письмових транскриптов, що містять фонетичні, граматичні та лексичні особливості північних діалектів, показав, що носії англійської мови не відчувають труднощів у розумінні більшості фраз, запропонованих для інтерпретації, але втрата інтересу до відповіді обумовлена складною системою транслітерації стала результатом $24 \%$ пропозицій, залишених без відповіді. Реципієнти зіткнулися 3 труднощами тільки на фонетичному рівні.

Статистика свідчить про те, що носії української мови, які вивчають англійську мову, не можуть безпомилково визначити особливості регіонального типу вимови на всіх трьох рівнях (11,7\% вірних відповідей, $57,5 \%$ питань залишено без відповіді), так як сприйняття північних акцентів носіями української мови відбувається на тлі раніше освоєної норми британського варіанту англійської мови.

Дослідження, проведене в двох групах реципієнтів на основі письмових джерел, ставило перед собою завдання порівняти та проаналізувати ступінь розуміння північних діалектів носіями англійської мови та україномовними білінгвами. Результати дослідження показали, що, відмінності систем голосних в якісній та кількісній відносинах, а також модифікації приголосних звуків у зв' язному мовленні не заважають спілкуванню носіїв англійської мови 3 різних регіонів, але перешкоджають адекватному сприйняттю україномовними білінгвами. У той час як носії мови ідентифікують північні діалекти на трьох рівнях - лексичному, граматичному i, найголовніше в даному дослідженні, фонетичному, для україномовних білінгвів інтерпретація фонетичних особливостей північних діалектів представляє велику трудність, незважаючи на те, що всі реципієнти володіють стандартним варіантом британської англійської мови.

Висновки 3 дослідження. Підводячи підсумки аналізу фонетичного дослідження, проведеного на основі письмових транскриптів звучащої діалектно-забарвленої мови та усного мовлення носіїв північних діалектів Англії, необхідно ще раз підкреслити, що при сприйнятті звучащої іноземної мови учасник спілкування в ході декодування сенсу висловлювання звертається до власних мовних знань, отримує модельний світ, і далі зіставляє даний модельний світ зі своїм власним уявленням. Результатами дослідження 
була підтверджена висунута гіпотеза по першому типу фонетичного дослідження. Фонетичні відмінності північних діалектів більшою мірою ускладнюють адекватне сприйняття звучащої діалектно-забарвленої мови україномовними білінгвами, а також носіями англійської мови. Було визначено, що відмінності систем голосних в якісній та кількісній відносинах, а також модифікація приголосних звуків у зв'язному мовлення перешкоджають адекватному розумінню сенсу реципієнтами.

Наше дослідження показало, що особистий мовний та соціокультурний досвід в групі А - носіїв англійської мови - вплинув на їхні відповіді. Спостерігалася висока ступінь адекватності інтерпретації змісту діалектнозабарвленої мови на фонетичному та лексичному рівнях та задовільний ступінь адекватності в випадках визначення граматичних невідповідностей. Форма пред'явлення матеріалу - звучаща мова у вигляді письмових транскриптов - викликала утруднене сприйняття в даній групі реципієнтів, що призвело до низького ступеня адекватності інтерпретації.

У групі Б - україномовних білінгвів - спостерігався задовільний ступінь адекватності інтерпретації деяких фонетичних та граматичних особливостей північних діалектів та низький ступінь адекватності декодування на лексичному рівні. Лінгвістичні та паралінгвістичні фактори в промови впливають на глибину розуміння усного дискурсу. Просодичні та паралінгвістичні характеристики 3 одного боку полегшують сприйняття емоційної сторони тексту, 3 іншого боку ускладнюють розуміння інформаційної парадигми висловлювання.

На другому етапі фонетичного дослідження було встановлено, що різна повнота розуміння обумовлена стандартним набором труднощів в текстах, головним чином фонетичного та просодичного характеру. Наявність лінгвокультурологічних аспектів, характерних для північного регіону Англії перешкоджало глибокому розумінню суті висловлювання, а також сприйняття комічності ситуації. Було встановлено, що для україномовних білінгвів розуміння мови на слух становить значні труднощі. Найважче визначаються не емоції та манера мови, а відбувається процес смислового сприйняття.

Відсутність соціально-культурного досвіду спілкування україномовних білінгвів 3 носіями північних діалектів Англії, володіння фонетичною базою стандартної англійської мови та підсвідоме проведення 3 ним паралелі, відсутність знань про основні відмінні характеристики північних акцентів, нетиповий мелодійний малюнок звучащих текстів змушує нас стверджувати, що всі реципієнти - носії англійської мови як іноземної знаходяться на початковому, загальному рівні глибини розуміння за класифікацією I.O. Зимньої [6], що в реальному спілкуванні призвело б до невдалої комунікації.

Разом 3 тим, ступінь звикання реципієнтів до звучання північних акцентів привела до того, що рівень сприйняття та адекватної оцінки завдань, спрямованих на характеристику манери оформлення мови мовця, а також визначення типу емоцій, стає тим вище і правильніше, ніж більше епізодів 
було представлено на прослуховування. При визначенні емоційності мови випробовувані показали кращі результати, ніж в завданнях на розуміння інформаційного боку тексту, що може свідчити про те, що незалежно від того, чи розуміє реципієнт, про що говорить диктор чи ні, він може визначити його емоційний стан.

Таким чином, в дослідженні, проведеному на матеріалі звучащіх текстів, в результаті другого типу аудитивного аналізу було встановлено, що просодія, як складова фонетичного аспекту мови безпосереднім найактивнішим чином впливає на досягнення ефективності комунікації. Адекватне декодування інформації, закладеної в тембральні характеристики висловлювання, дозволяє оптимізувати процес спілкування між мовцями. Крім того, було визначено, що мовна компетенція реципієнтів не впливає на їх здатність інтерпретувати регіонально маркований текст, а саме сприймати емоційну сторону усного дискурсу і розуміти зміст тексту. Суть дослідження полягала в дослідженні глибини сприйняття північного діалекту україномовними білінгвами. В результаті фонетичного аналізу англійської усної мови не тільки була підтверджена гіпотеза, що розуміння змісту уривків представляє велику трудність, ніж визначення та характеристика емоцій виражених в тексті, але і виявлено специфічні труднощі процесу сприйняття діалектно-забарвленої мови україномовними білінгвами.

\section{ЛITEPATУРА}

1. Бродович О.И. Диалектная вариативность английского языка: аспекты теории. Л., 1988.

2. Бернштейн С.И. Вопросы обучения произношению (применительно к преподавателю русского языка иностранцам). Bопросы фонетики $u$ обучения произношению. М., 1975. С. 5 - 62.

3. Бубнова Г.И. Основные интонационные контуры: акустическая форма и функции, выполняемые в устнопорождаемой монологической речи. Экспериментальные исследования звучащей речи: сб. науч. тр. РАН Ин-т языкознания / отв. ред.: К.И. Долотин, А.М. Шахнарович. М., 1998. С. 3 - 28.

4. Давыдов М.В., Рубинова О.С. Ритм английского языка: монография. М.: Диалог - МГУ, 1997. 115 с.

5. Жирмунский В.М. Немецкая диалектология. М. - Л.: 1956. С. 635.

6. Зимняя И.А. Психология обучения неродному языку. М.: Рус. яз., 1989. $219 \mathrm{c}$.

7. Крицберг Р.Я. Дивергенция и конвергенция региональных вариантов английского языка: автореферат ... д-ра филол. наук: 10.02.04. / Киевский национальный лингвистический университет. Киев, 2001. 35 с.

8. Ледяева Е.В. Интонационное оформление дискурсивных элементов в английской разговорной речи (на материале йоркширского диалекта 
английского языка): автореф. ... к-та филол. наук / Ивановский государственный университет. Иваново 2002. 19 с.

9. Маковский М.М. Английская диалектология. Современные английские территориальные диалекты Великобритании. М.: КомКнига, 2005. 84 с.

10.Травкина А.Д. Типологически релевантная вариативность стандартной произносительной формы английского слова: автореф. дис. ... д-ра филол. наук: 10.02.20 / Тверской государственный университет. Тверь, 2001. $36 \mathrm{c}$.

11.Шевченко Т.И. Современное английское произношение: формы и факторы развития. Проблемы современной фонетики: сборник научных трудов МГЛУ. Вып. 507. М. 2005. С. $202-210$.

12.Ярцева В.Н. Развитие национального литературного английского языка. М.: Едиториал УРСС, 2004. 288 c.

13. Cruttenden A. Gimson's Pronunciation of English. London: Edward Arnold, 2001. $320 \mathrm{p}$.

14. Crystal D. Cambridge Encyclopedia of the English Language. Cambridge, 1995. $429 \mathrm{p}$.

15.Dyer S. Dialect of the West Riding of Yorkshire. A short history of Leeds and other towns. Wakefield: S.R. publ., 1970. 142 p.

16. Honey J. Does accent matter? The Pygmalion Factor. London, 1989. 208 p.

17. Honeybone P. Why everyone should be interested in Northern English 't-r'. Workshop on Northern Englishes. Lancaster University, March 2006. URL: http://www.englang.ed.ac.uk/people/patrick2.html

18. Kellett A. The Yorkshire Dictionary of Dialect, Tradition and Folklore. Smith Settle, 2002. 217 p.

19.Labov W. Principles of Linguistic Change. Volume 1: Internal Factors. Cambridge: Blackwell, 1994. 641 p.

20. Trudgill P. The Dialects of England. Oxford: Blackwell Publishers, 1990. 176 p.

21.Wakelin M.F. Discovering English Dialects. Aylesbury (Bucks): Shire Publications, 1978. 63 p.

22. Watson K. Lenition and segmental interaction: evidence from Liverpool English (and Spanish). 2006. 16 p.

23. Wells J.C. Accents of English. Vol.11. The British Isles. Cambridge: Cambridge university press, $1982.465 \mathrm{p}$. 